\title{
自律走行自転車ロボットの安定化走行制御*
}

\author{
佐口太一*1, 吉田和夫*2, 高橋 正 樹*3
}

\section{Stable Running Control of Autonomous Bicycle Robot}

\author{
Taichi SAGUCHI*4, Kazuo YOSHIDA and Masaki TAKAHASHI \\ ${ }^{* 4}$ Department of System Design Engineering, Keio University, \\ 3-14-1 Hiyoshi, Kohoku-ku, Yokohama-shi, Kanagawa, 223-8522 Japan
}

\begin{abstract}
Bicycle is the unstable system in itself. Although there are two methods of steering a handle and moving a weight in order to make a bicycle stable, it is shown that the former is more effective than the latter. This study deals with modeling and stabilizing control problems of a two-wheel bicycle. In the modeling, wheels side slip is taken into consideration. In the control, an optimal feedback control for stable running control is obtained. An autonomous bicycle robot is further developed. As a result of experiment, it is shown that the bicycle robot is able to run straight and turn stably. The effectiveness of the two-wheel bicycle model and control law are demonstrated.
\end{abstract}

Key Words : Bicycle, Modeling, Moving Robot, Motion Control, Optimal Control, Handle Control

\section{1. 緒言}

自転車は人間の力を借りなければ安定走行できな い不安定な系である.この自転車を制御により安定化 させることに興味がもたれ，研究されている．自転車 の安定走行の実現により, 将来的には自転車の機動性 を活かし，自動車が侵入できない狭い通路でも通行で きる自律ロボットへの応用など考えられる.

二輪車のモデルは Sharp ${ }^{(1)}$ により提案されているが, 厳密なモデルのため複雑であり, 自転車の姿勢安定化 のための制御系設計には適さない，また，自転車の自 律走行を目的として Getz ${ }^{(2)}$ が，ピッチ運動やキャスタ 角を除いた簡易な非線形モデルの自転車に厳密な非線 形フィードバックを適用している. しかし, 実験で検 証を行ってはおらず, 実際に安定走行させるにはより 簡易に制御系設計可能なモデルが必要であるといえる. そこで，自転車ロボットを製作して安定化を試みて いる研究が近年盛んに行われている. 佐藤ら ${ }^{(3)}$ は重心移 動を用いることで主に静止状態での自転車の安定化を 行っている. 小田ら ${ }^{(4)}$, Tsai $ら^{(5)}$, 仁木ら ${ }^{(6)}$ はハンドル 操舵による走行安定化を, 山北ら(7)は重心移動による走 行安定化を試みている. 小田らはモデルを用いずにゲ インの調整により，Tsai らは倒立振子のモデルと自転 車の地面との拘束条件を幾何的に表して組み合わせた

* 原稿受付 2006 年 12 月 19 日.

*1 学生員, 慶應義塾大学大学院理工学研究科(函223-8522 横 浜市港北区日吉 $3-14-1$ ).

*2 正員, フェロー, 慶應義塾大学理工学部.

*3 正員, 慶應義塾大学理工学部.

E-mail : saguchi@yoshida.sd.keio.ac.jp
線形モデルを基に制御則を構築し，安定化を試みてい るが実験による十分な安定走行はできていない，仁木 らも Tsai らと同様のモデルを用いてローラー台上での 安定化を実現している。 また, 2005 年に侏村田製作所 が慣性ロータの反力を利用した自転車ロボット「ムラ タセイサク君」を開発して安定走行を実現している ${ }^{(8)}$.

一方, 著者らは重心移動に比ベハンドル操舵の方が 走行時の自転車の安定化に有効であることを既に示し ている(9). そのため先駆けてハンドル操舵による安定化 に着目し, タイヤの横すべりおよびヨーイングとロー リングの連成を考慮した線形自転車モデルを構筑して きた. 構筑したモデルではタイヤの横すべりを考慮し ていることが特徵であり, コーナリングパワーを調整 することで異なる路面上でも対応できると考えられる.

本論文では，著者らが構筑してきたタイヤのすべり およびヨーイングとローリングの連成を考慮した簡易 な線形自転車モデルを提示する. 安定化の制御として は, 既に本研究(9)で有効性が示されているハンドル操舵 を制御する方法を用い，最適制御手法により制御則を 確立する. また, 市販の自転車にセンサ, アクチュエ 一夕等を取り付け製作した自律走行自転車ロボットを 用いて安定走行実験を行い，構築した自転車モデルの 妥当性および制御則の有効性を実証する.

構筑した自転車モデルの妥当性を示せたことによ り，モデルベースによる様々な制御系設計が可能であ ると考えられる. そこで本論文の最後に, 自転車を傾 斜させることでカーブ走行を行う制御則を設計し，こ れにより容易にカーブ走行を実現できることを示す. 


\section{2. 自転車のモデリング}

タイヤの横すべりおよびローリングとヨーイングの 連成を考慮して導出した本論文で提示する自転車の線 形簡易モデルについて述べる，まず，自転車の姿勢安 定化を行うとき, ハンドル操舵によりタイヤに横すべ りが生じる. ゆえに, タイヤに働く力を考慮する必要 がある.このことを表現するために，車両工学で述べ られる自動車の二輪簡易モデルを用いる. そして, 自 転車の倒れるという性質を倒立振子モデルにより表現 する.これら二つのモデルを組み合わせることで自転 車モデルを構築する.

まず，二輪簡易モデルについて述べる．移動座標系 上で表した走行する自転車のモデルを図 1 に, 上方か ら見たモデルを図 2 に示す。 まず， $\beta$ をタイヤの横す ベり角, $\omega$ をヨ一方向角速度, $I_{z z G}, I_{x x G}$ をそれぞれ 自転車のヨーイング, ローリング慣性モーメントとし, 前後のタイヤに働くカとしてコーナリングフォース $F_{f}, F_{r}$, キャンバスラスト $F_{c f}, F_{c r}$ とする. このと き, 移動する自転車の座標系に固定した重心点の並進 運動，およびヨーイング方向の回転運動に関してタイ ヤに働く力から自転車の運動を記述する式(1)(2)が導 出される.

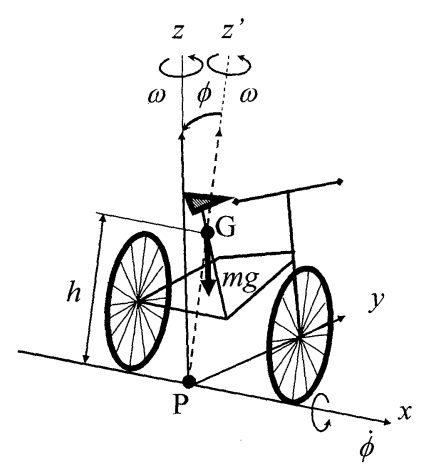

Fig.1 Two-wheel bicycle model

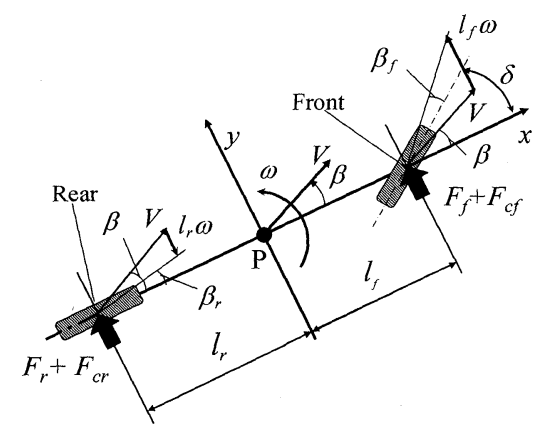

Fig.2 Two-wheel bicycle model (horizontal plane)
- 横方向

$$
\begin{aligned}
& m V\left(\frac{d \beta}{d t}+\omega\right)-m h \frac{d^{2} \phi}{d t^{2}}=F_{f}+F_{r}+F_{c f}+F_{c r} \\
& \text { ・ } \\
& I_{z z G} \frac{d \omega}{d t}=l_{f} F_{f}-l_{r} F_{r}+l_{f} F_{c f}-l_{r} F_{c r}
\end{aligned}
$$

ここで前後輪のタイヤのコーナリングパワーをそれ ぞれ $K_{f}, K_{r}$ とする. 横すべり角が小さければ $F_{f}, F_{r}$ はそれぞれ横すべり角 $\beta_{f} ， \beta_{r}$ に比例する．そこで， 横すべり角は微小であると仮定する. 図 2 のように角 度を反時計回りを正とすると，横すべり角が正のとき， 負の向きにコーナリングパワーは働くため, $F_{f}, F_{r}$ は それぞれ以下のように表される.

$$
\begin{aligned}
& F_{f}=-K_{f} \beta_{f}=-K_{f}\left(\beta+\frac{l_{f}}{V} \omega-\delta\right) \\
& F_{r}=-K_{r} \beta_{r}=-K_{r}\left(\beta-\frac{l_{r}}{V} \omega\right)
\end{aligned}
$$

ここで $\delta$ はタイヤの実操舵角である.

また，自転車の場合，車体のロール運動によって生 じるキャンバ角はロール角 $\phi$ に等しい. キャンバスラ ストはロール角が微小であればロール角に比例する. そこで, ロール角は微小であると仮定する. 前後輪そ れぞれに㗢くキャンバスラスト $F_{c f}, F_{c r}$ は, キャンバ スラスト係数 $K_{c f}, K_{c r}$ を用いてそれぞれ以下のように 表される.

$$
\begin{aligned}
& F_{c f}=-K_{c f} \phi \\
& F_{c r}=-K_{c r} \phi
\end{aligned}
$$

次に，倒立振子のモデルについて述べる. ヨーイン グ方向の回転運動により, 重心に遠心力が働く. そこ で， $x$ 軸まわりのモ一メントの釣り合い式は(7)式で表 すことができる.

\section{・ローリング方向}

$$
\left(I_{x x G}+m h^{2}\right) \frac{d^{2} \phi}{d t^{2}}-m h V\left(\frac{d \beta}{d t}+\omega\right)=m g h \phi
$$

以上(1)，(2)式に(3)(4)(5)(6)式を代入した式，および (7)式が提案する自転車の運動方程式である.

\section{3. 安定化走行制御}

3-1 状態方程式導出した運動方程式を基に安 定化走行制御則を設計する. そのために運動方程式か ら状態方程式を求める. その際, 用いた物理パラメー 夕を表 1 にまとめる. また, 4 章で述べる自転車ロボッ トでは DC サーボモータでハンドルを操舵する。つま 
りハンドル操舵に遅れが生じるため，モータモデルを 導入し，状態方程式に組み込む必要がある．モータの トルク方程式は以下のようになる.

$$
\left(\frac{J_{0}}{k^{2}}+J_{1}\right) \frac{d^{2} \theta}{d t^{2}}+b \frac{d \theta}{d t}=K i
$$

ここで, $i$ は入力電流, $\theta$ はモータの軸の回転角, $J_{0}$ はハンドル操舵部の慣性モーメント，J1はモータのシ ヤフトと減速器からなる慣性モ一メントである. また, モ一タの軸の回転角 $\theta$ とハンドル操舵角 $\delta$ との間には 以下の関係式が成り立つ.

$$
\theta=-k \delta
$$

2 章で提案した自転車モデル,およびモ一タのトルク方 程式をあわせて拡大系として状態空間方程式を導出す る. ここで $u$ はハンドル操舵用モ一タへの入力電流で ある.

$$
\begin{aligned}
\dot{\boldsymbol{x}} & =\boldsymbol{A} \boldsymbol{x}+\boldsymbol{B} u \\
\boldsymbol{y} & =\boldsymbol{C} \boldsymbol{x} \\
\boldsymbol{x} & =\left[\begin{array}{llllll}
\phi & \dot{\phi} & \theta & \dot{\theta} & \omega & \beta
\end{array}\right]^{T} \\
\boldsymbol{A} & =\left[\begin{array}{cccccc}
0 & 1 & 0 & 0 & 0 & 0 \\
a_{1} & 0 & a_{2} & 0 & a_{3} & a_{4} \\
0 & 0 & 0 & 1 & 0 & 0 \\
0 & 0 & 0 & a_{5} & 0 & 0 \\
a_{6} & 0 & a_{7} & 0 & a_{8} & a_{9} \\
a_{10} & 0 & a_{11} & 0 & a_{12} & a_{13}
\end{array}\right] \\
\boldsymbol{B} & =\left[\begin{array}{lllllll}
0 & 0 & 0 & b_{1} & 0 & 0
\end{array}\right]^{T}
\end{aligned}
$$

Table 1 Values of bicycle robot parameters

\begin{tabular}{|c|c|c|}
\hline Symbol & Parameter & Value \\
\hline$m$ & Mass of bicycle robot & $41.82(\mathrm{~kg})$ \\
\hline$V$ & Velocity of bicycle robot & $1.6(\mathrm{~m} / \mathrm{s})$ \\
\hline$h$ & Height of center of gravity & $0.586(\mathrm{~m})$ \\
\hline$l_{f}$ & Length from front wheel to center of gravity & $0.68(\mathrm{~m})$ \\
\hline$l_{r}$ & Length from rear wheel to center of gravity & $0.32(\mathrm{~m})$ \\
\hline$K_{f}$ & Cornering power for front wheel(carpet) & $2000(\mathrm{~N} / \mathrm{rad})$ \\
\hline$K_{r}$ & Cornering power for rear wheel(carpet) & $2800(\mathrm{~N} / \mathrm{rad})$ \\
\hline$K_{f}$ & Cornering power for front wheel(tiling) & $1500(\mathrm{~N} / \mathrm{rad})$ \\
\hline$K_{r}$ & Cornering power for rear wheel(tiling) & $2100 \mathrm{~N} / \mathrm{rad})$ \\
\hline$K_{c f}$ & Camber thrust factor for front wheel & $333(\mathrm{~N} / \mathrm{rad})$ \\
\hline$K_{c r}$ & Camber thrust factor for rear wheel & $466(\mathrm{~N} / \mathrm{rad})$ \\
\hline$I_{x a G}$ & Inertia moment of center of gravity(x-axis) & $3\left(\mathrm{~kg} \cdot \mathrm{m}^{2}\right)$ \\
\hline$I_{z G}$ & Inertia moment of center of gravity $(\mathrm{z}-\mathrm{axis})$ & $3\left(\mathrm{~kg} \cdot \mathrm{m}^{2}\right)$ \\
\hline$J_{0}$ & Inertia moment of handle axis & $0.171\left(\mathrm{~kg} \cdot \mathrm{m}^{2}\right)$ \\
\hline$J_{1}$ & Inertia moment of shaft axis & $0.021\left(\mathrm{~kg} \cdot \mathrm{m}^{2}\right)$ \\
\hline$K$ & Torque constant & $2.92(\mathrm{~N} \cdot \mathrm{m} / \mathrm{A})$ \\
\hline$k$ & Reduction gear ratio & 2 \\
\hline$b$ & Viscous friction constant & 0.001 \\
\hline & & \\
\hline & & \\
\hline
\end{tabular}

$$
C=\left[\begin{array}{llllll}
1 & 0 & 0 & 0 & 0 & 0 \\
0 & 1 & 0 & 0 & 0 & 0 \\
0 & 0 & 1 & 0 & 0 & 0 \\
0 & 0 & 0 & 1 & 0 & 0
\end{array}\right]
$$

3 -2 安定化走行制御則 次に状態方程式を基に フィードバック制御によりすべての状態量を 0 にする レギュレータ問題を解く. 本研究では(14)式で表される 評価関数 $J$ を最小にする最適制御問題を解くことでフ イードバックゲイン $\boldsymbol{F}$ を導出する. 重み行列は数值計 算上で自転車が安定走行できるよう調節して決定した. $\boldsymbol{Q}$ に関してはロール角を 0 にすることが目的であるた め，ロール角に重きをおいた。

$$
\begin{aligned}
J & =\int_{0}^{\infty}\left(\boldsymbol{x}^{T} \boldsymbol{Q x}+r u^{2}\right) d t \\
u & =-\boldsymbol{F} \boldsymbol{x} \\
\boldsymbol{Q} & =\operatorname{diag}\left[\begin{array}{lllllll}
4000 & 2000 & 1 & 1 & 1 & 1
\end{array}\right], \quad r=15 \\
\boldsymbol{F} & =\left[\begin{array}{llllll}
-39.7 & -15.4 & 5.96 & 0.571 & -0.0724 & 28.1
\end{array}\right]
\end{aligned}
$$

また, 状態量のうち, ヨ一方向角速度およびタイヤ の横すべり角の状態量はカルマンフィルタを用いて状 態推定を行う.

$3 \cdot 3$ ハンドル操蛇制御則 前節で導出したモー タへの制御入力を実際のモ一タに入力して得られる挙 動はモデル化誤差や外乱の影響により所望の結果が得 られるとは限らない，そこで自律走行自転車口ボット のハンドル操舵用モータの制御には目標指令值に対し て望ましい応答を示すモデルを付加し, その内部状態 変数を用いて拡大系を構築するモデル追従型サーボ系 (10)を用いる. 具体的には, (15)式で導出した制御入力を $u_{r}$ とし, モ一タモデルに加えたとき得られるハンドル 操舵角, 角速度を計算, その結果と実際の角度, 角速 度との誤差から PI制御により実際にモー夕に入力する 電流 $u$ を導出することで,ハンドル操舵の制御を行う. ここで目標追従モデルを次のようにする.

$$
\left\{\begin{array}{l}
\dot{x}_{r}=A_{r} x_{r}+B_{r} u_{r} \\
y_{r}=C_{r} x_{r}
\end{array}\right.
$$

ハンドル操舵用モータへの制御入力は次のようになる.

$$
\begin{gathered}
u=-F_{1} x_{m}-F_{2} \int_{0} y_{e} d t-F_{3} x_{r} \\
\left(y_{e}=y_{r}-x_{m}\right)
\end{gathered}
$$

ゲインは最適制御手法を用いて決定する。これら をふまえ, 姿勢安定化走行制御則の全体の制御系 構成図を図 3 に示す。 


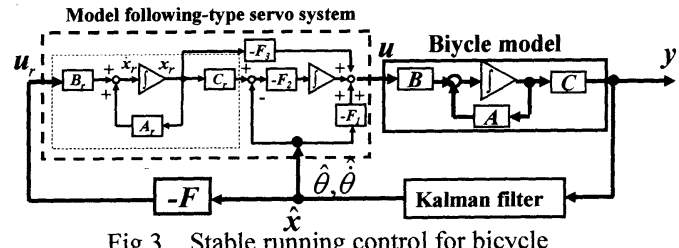

Fig.3 Stable running control for bicycle

\section{4. 自律走行自転車ロボットシステム構成}

提案した自転車モデルの妥当性を検証するためには， 安定化走行制御則による自転車の走行害験の結果と数 值計算結果を比較する必要がある，そこで実際に自転 車ロボットを製作する. 本章では製作したハンドル操 舵型自律走行自転車ロボットについて述べる. 図 4 に 示すように市販の自転車を改造することにより自転車 ロボットを製作した. システムはセンシングシステム, アクチュエータシステム, 情報処理システムの三つか ら構成されている. 全体のシステムに関して図 5 に示 し, 以下詳細を述べる.

$4 \cdot 1$ センシングシステム走行する自転車のロ 一ル角，ロール角速度，およびハンドルの操舵角度を センサにより計測する. ロール角は重力加速度の方向 を検出する傾斜角センサ（緑測器製 PMP-S20T）を用 い，ロール角速度はジャイロセンサ（Silicon Sensing Systems Japan Ltd.製 CRS03-02）を用いて計測される. ハンドルの操舵角度はモータ軸に取り付けたロータリ エンコーダにより計測される。ここで, 傾斜角センサ は加速度に影響され誤差が生じるため，ジャイロセン サで補正する(11)ことでロール角を導出する.

4・2 アクチュエータシステム アクチュエータ システムでは DC サーボモータが指令に従ってハンド ル操舵およひ駆動力の供給を行う。駆動力はモータ軸 に取り付けたスプロケットを自転車のチェーンに介し て後輪に伝える. 一方自転車のハンドルにアームを取 り付け，サーボモータを接続することにより，前輪の ハンドルを駆動させる.

4 -3 情報処理システム 情報処理システムでは自 転車ロボットへの入力電流量を計算する $\mathrm{PC}$ 部, センサ 情報を処理し，アナログ信号をデジタル信号に変換す る $\mathrm{AD}$ 変換ボード，エンコーダ情報を処理するエンコ ーダカウンタボード, モータドライバー PC から指令を 送るためにデジタル信号をアナログに変換する DA 変 換ボードから構成される.PC の OS にはRed Hat Linux9 を用い，プログラムの開発言語には C+十言語を使用す る.

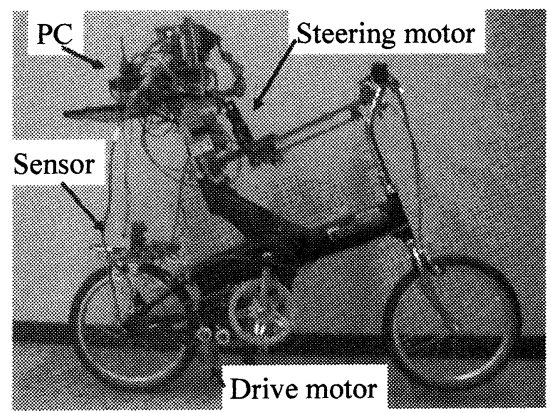

Fig.4 Autonomous bicycle robot

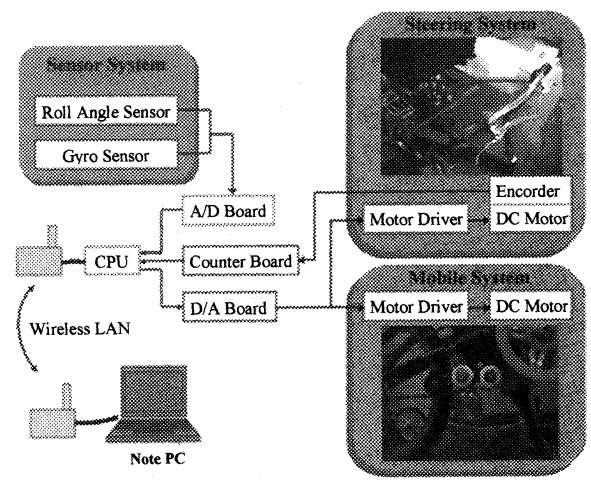

Fig.5 System for autonomous bicycle robot

\section{5. 直立安定化走行実駼}

$5 \cdot 1$ 実験条件 路面状態が䋐廹，およびタイル 貼りの廊下という異なる環境下において，路面状況を 考慮してコーナリングパワー，キャンバスラスト係数 の值を調整して走行実験をする．これらの值は塚田 ${ }^{(12)}$ の測定結果を参考に推定し, 実験と数值計算の結果を 照合することで決定した．また，本研究における安定 化走行制御実験に際して，走行開始および停止の指令 は別に用意したノートPCから無線LAN を通じて実行 する.ノートPC は実行ファイルの転送および害行指令 用であり，計算などのプログラム実行は自転車ロボッ 卜に搭載された PC で行う.計算およびモータへの指令 の制御周期は $1.5 \mathrm{msec}$ とする. 初期状態は直立状態近 傍とする。

5-2 実験結果 直立安定化走行実験のロール角 およびハンドル操舵角の時刻歷応答を図 6 に示す。こ のとき路面は絨掞という環境下で実験を行った．この 結果，傾斜した方向にハンドルを操舵することで自転 車ロボットが倒れることなく安定に走行していること を確認できる．また路面がタイル貼りの環境下におい て，人為的に自転車ロボットの側面を叨き，外力を加 えた. 実験によるロール角の時刻歴結果と数値計算上 
の結果が適合するように外力の值を推定する. 2 章で提 案したモデルの数值計算によるロール角, およびハン ドル操舵角の時刻歴応答の比較をそれぞれ図 7, 図 8 に示す.この結果より, 実験と数值計算によるロール 角およびハンドル操舵角の挙動がほぼ一致しているこ とが示された．ゆえに提案したモデルの妥当性を実証 することができたといえる.なおコーナリングパワー の值の違いに対するロバスト性は高く, 絨㘪の路面状 況では実験および数值計算において推定值を $1000 \mathrm{~N} / \mathrm{rad}$ 程度変化させた状況においても安定走行を 実現した。ロバスト性が高い一方，コーナリングパワ 一の推定值の信頼度も低いといえる.

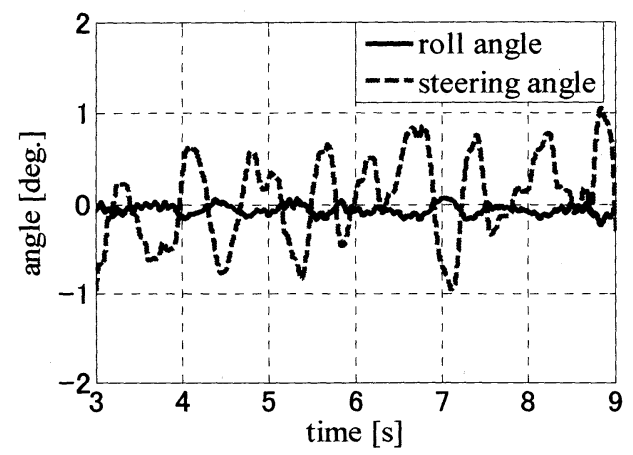

Fig.6 Result of Stable running control

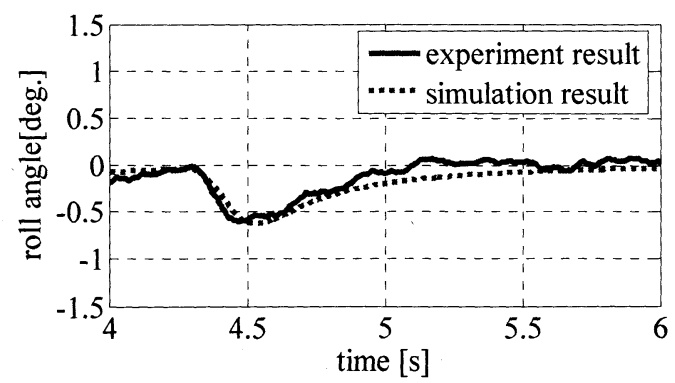

Fig.7 Comparison of simulation and experiment results (roll angle $\phi$ )

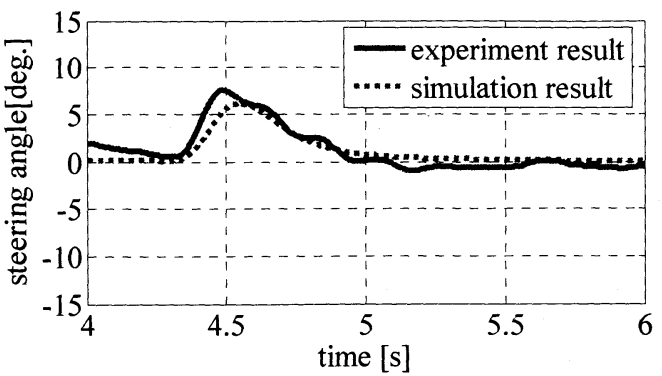

Fig.8 Comparison of simulation and experiment results (handle steering angle $\delta$ )

\section{6. カーブ走行制御}

6-1 カ一ブ走行制御則 前章の結果より，提案 した自転車モデルの妥当性を示すことができた：この ことから提案した自転車モデルを用いることで，モデ ルベースによる様々な自転車の制御則の設計が可能で あるといえる．本論文では適用例として，カーブ走行 制御則の設計を行った結果を示す。制御方法はハンド ルを操舵し自転車を傾斜させた状態で安定にする。こ れによりカーブ走行を実現できる. カーブ時における 走行軌道を曲率半径 $\rho$ で与え, 遠心力と重力の釣り合 いから，以下のように目標ロール角 $\phi_{r e f}$ を導出する。

$$
\phi_{r e f}=\frac{V^{2}}{\rho g}
$$

そして，その目標ロール角に自転車ロボットのロー ル角を追従させる. 目標ロール角はステップで与える. このとき最適サ一ボ問題として，ロール角と目標ロー ル角との偏差を積分し, 定常偏差なく追従させる.

$$
\begin{aligned}
& u=-\boldsymbol{F} \boldsymbol{x}+\boldsymbol{K} z \\
& \dot{z}=\phi_{\text {ref }}-\phi
\end{aligned}
$$

フィードバックゲインは最適サーボ問題を解くこと により以下のように導出される.

$$
\begin{aligned}
\boldsymbol{F} & =\left[\begin{array}{llllll}
-62.4 & -12.0 & 4.58 & 0.447 & -0.0437 & 21.8
\end{array}\right] \\
\boldsymbol{K} & =-45.3
\end{aligned}
$$

また，安定化走行制御と同様にヨー方向角速度およ びタイヤのすべり角の状態量はカルマンフィルタを用 いて状態推定を行う。

$6 \cdot 2$ カ一ブ走行実験 カーブ走行制御系を用い てカーブ時における安定走行実験を行う。実験環境お よび初期条件は 4.4 節で示したものと同様とする，制 御開始から約 3 秒経過後に目標ロール角を $0^{\circ}$ から曲 率より導出された目標ロール角まで変化させる.この とき, 曲率半径 $2 \mathrm{~m}$ と $3 \mathrm{~m}$ から目標ロール角を計算し, それぞれにおいて右回転，左回転の指令を与え実験を 行った. 実際のカーブ走行の様子を約 1.2 秒毎にとらえ た写真を図 9 に示す．また，曲率半径 $3 \mathrm{~m}$ ，左回転の指 令を与えたときのロール角，ハンドル操舵角の時刻歷 応答を図 10 に示す．また，図 10 から，目標ロール角 に自転車のロール角が追従できていることを確認でき る. 実際の走行軌道に関しては計測するセンサを導入 していないため正確には把握できないが，目標とする 曲率半径 $2 \mathrm{~m}$ のとき, 実際には約 $2.5 \mathrm{~m}$ 程度, $3 \mathrm{~m}$ のと き実際には $4 \mathrm{~m}$ 程度でのカーブ走行を確認した. 目標 


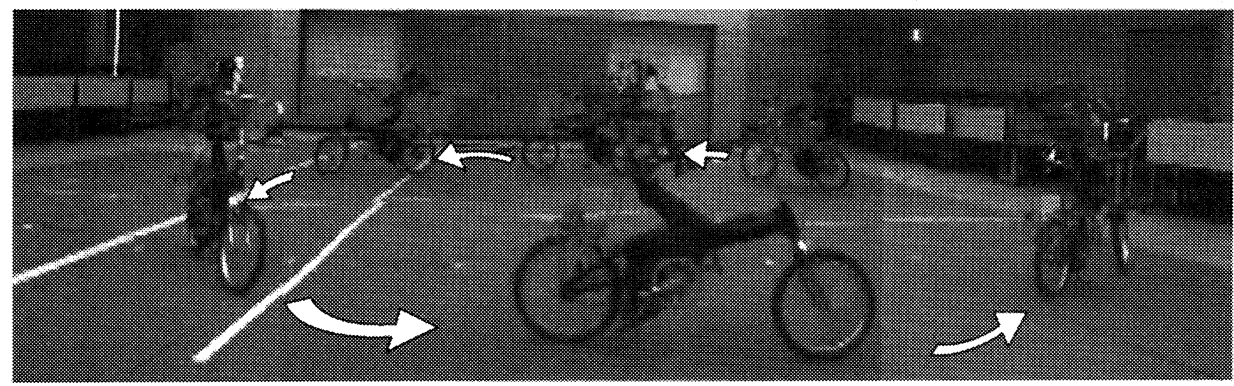

Fig.9 Trajectory of curve running

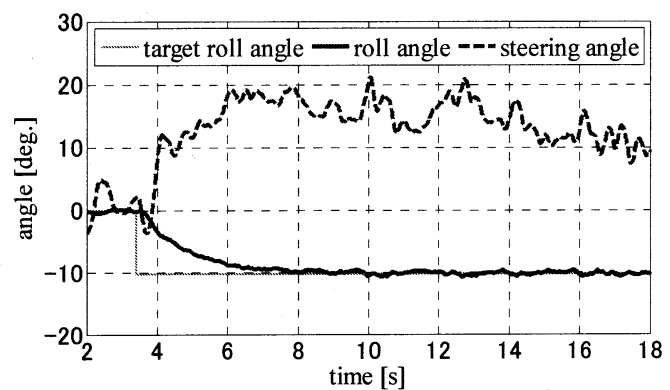

Fig.10 Result of curve running control

とする曲率半径と害際との誤差の原因は, 目標ロール 角に追従させているだけで軌道情報をフィードバック していない，旋回運動による遠心力により傾斜角セン サの出力に長時間におよぶ誤差が生じ補正処理で正確 に補正できなくなっている, 走行速度が安定しない, などの影響が考えられる. 以上より, 走行軌道に誤差 が生じるものの, 最適サーボ問題を解くだけで容易に カーブ走行を実現することができることを実証した.

\section{7. 結語}

タイヤの横すべりおよびローリングとヨーイングの 連成を考慮した簡易線形自転車モデルを構築した. その モデルに基づきハンドル操舵による安定化走行制御則 を最適制御手法により確立した. また, 実際に自律走行 自転車ロボットを製作し, 安定走行実験を行った. 直立 安定走行およびカーブ走行においてそれぞれ自転車口 ボットが倒れずに走行することを実現した. そして, 直 立安定走行実験の結果と数值計算結果との比較により, 整合性を取ることができ, 構築したタイヤの横すべりを 考慮した自転車モデルの妥当性を実証した.

\section{謝辞}

過去に自転車ロボット開発に携わった小西康晴氏, 村岡大介氏の尽力により本研究が実現したことを記し， 謝意を表す. また, 本研究は, 文部科学省平成 15 年度 21 世紀COEプログラム「知能化から生命化へのシス
テムデザイン」によるものであることを記し，謝意を 表す.

\section{文献}

(1) Sharp,R.S., The Stability and Control of Motorcycles, Journal Mechanical Engineering Science, Vol.13, No.5 (1971), pp. 316-329.

(2) Getz, N.H. and Marsden, J.E., Control for an Autonomous Bicycle, IEEE International Conference on Robotics and Automation, (1995), pp. 1397-1402.

(3) Satoh, H. and Namerikawa, T., Modeling and Robust Attitude Control of Stationary Self-sustaining Two-wheeled Vehicle, Transactions of the Japan Society of Mechanical Engineers, Series C, Vol.71, No.719, (2006), pp.2130-2136.

(4) Oda, Y., et al., Study on the autonomous run by integrated control of a bicycle. In the case of control of a handle steering angle and the amount of center-of-gravity movements, Japan Society of Mechanical Engineers Transportation and Logistics Conference, Vol.11, (2002), pp.97-100.

(5) Tsai, C.C., et al., Steering Control System Design and Implementation for Riderless Bicycle, Proceeding of International conference on Mechatronics Technology, Vol.7th, (2003), pp.203-208.

(6) Niki, H. and Murakami, T., An Approach to Self Stabilization of Bicycle Motion by Handle Controller, Transactions of the Institute of Electrical Engineers of Japan, Series D, Vol.125, No.8, (2005), pp.779-785.

(7) Yamakita, M. et al., Automatic Control of Bicycles with a Balancer, Conference of the Robotics Society of Japan (CD-ROM), Vol.23rd, (2005), pp.1E13.

(8) http://www.murataboy.com/

(9) Konishi, Y. and Yoshida, K., Modeling and Stabilizing Control for Dynamics of a Bicycle, Dynamics and Design Conference 2001 of the Japan Society of Mechanical Engineers, Vol.7th, (2001-4), pp. 456- 458.

(10) Nonami, K. and Nishimura, H., Basic of Control Theory by MATLAB (in Japanese), Tokyo Denki University Press, (1998), pp201-202

(11) Muto, K. and Abe, H., Three-dimensional posture angle sensor, Tokin technical review, Vol.26, (1999), pp. 69-73.

(12) Tsukada, Y., Characteristics of Bicycle Tires, Science Reports of Research Institute for Engineering Kanagawa University, No.6, (1983), pp23-31 